\title{
Elaboration of a xylazine and dexmedetomidine infusion regime which provides a constant level of sedation in horses
}

\author{
Christina Müller', Klaus Hopsterl, Charlotte Hopster-Iversen', Karl Rohn' und Sabine B. R. Kästner 2,3
}

Klinik für Pferde ${ }^{1}$ und Klinik für Kleintiere², Zentrum für Systemische Neurowissenschaften Hannover ${ }^{3}$, Institut für Biometrie, Epidemiologie und Informationsverarbeitung ${ }^{4}$, Stiffung Tierärztliche Hochschule Hannover, Germany

\begin{abstract}
Summary
The study was performed to elaborate equipotent constant rate infusion regimes of xylazine and dexmedetomidine in awake horses, which provide a constant level of sedation and may be suitable for constant rate infusion to be used as part of a total intravenous anaesthesia (TIVA) protocol in horses. Five adult, healthy university-owned horses were sedated three times for two hours with a washout period of 2 weeks between treatments. In group X the horses were sedated with $0.5 \mathrm{mg} / \mathrm{kg}$ bwt of xylazine IV, followed by a constant rate infusion (CRI) of $1 \mathrm{mg} / \mathrm{kg}$ bwt $/ \mathrm{h}$ xylazine. In group D1 horses received a bolus of $3.5 \mu \mathrm{g} / \mathrm{kg}$ bwt IV dexmedetomidine and a CRI of $5 \mu \mathrm{g} / \mathrm{kg}$ bwt $/ \mathrm{h}$. In D2 horses were treated as horses in group D1 but received additional boli of $0.5 \mathrm{mg}$ per horse of dexmedetomidine to reach the same reduction of nose-to-ground-distance of group X. Heart rate (HR), respiratory rate (RR) and nose-to-ground-distance were recorded every five minutes. Reaction to thermal stimulation of the skin over the nostrils and thermal threshold was tested. A two-way analysis of variance with repeated measurements was used to analyse data with an alpha of $5 \%$. The dosage of dexmedetomidine used in group D1 (3.5 $\mu \mathrm{g} / \mathrm{kg}$ bwt, IV and $5 \mu \mathrm{g} / \mathrm{kg} \mathrm{bwt} / \mathrm{h}$ ) was not equipotent to the xylazine dosage used in group X $(0.5 \mathrm{mg} / \mathrm{kg} \mathrm{bwt,} \mathrm{IV} \mathrm{and} 1 \mathrm{mg} / \mathrm{kg}$ bwt $/ \mathrm{h})$ and a calculated CRI of $7 \mu \mathrm{g} / \mathrm{kg}$ bwt $/ \mathrm{h}$ was necessary in group D2 to receive equisedation. All horses developed signs of mild to deep sedation including moderate ataxia. HR and nose-to-ground distance decreased significantly from baseline to sedation in all groups. RR decreased significantly from baseline to sedation in group D2. Thermal thresholds increased significantly above baseline from time 15 to 120 minutes in group X and D1 and from time 15 to 150 minutes in group D2. We concluded that all three dosing regimes are suitable to maintain a constant level of sedation with moderate signs of ataxia. A calculated CRI of $7 \mu \mathrm{g} / \mathrm{kg}$ bwt $/ \mathrm{h}$ dexmedetomidine after a bolus of 3.5 $\mu \mathrm{g} / \mathrm{kg}$ bwt was equisedative to a CRI of $1 \mathrm{mg} / \mathrm{kg}$ bwt $/ \mathrm{h}$ xylazine after a bolus of $0.5 \mathrm{mg} / \mathrm{kg}$ bwt.
\end{abstract}

Keywords: equine / xylazine / dexmedetomidine / sedation / CRI / anesthesiology

\section{Evaluierung einer Xylazin- und Dexmedetomidin-Dauertropfinfusion für die konstante Sedierung bei Pferden}

Xylazin und Dexmedetomidin gehören zur pharmakologischen Gruppe der Alpha-2-Adrenorezeptor Agonisten. Beide sind daher für die Sedierung beim Pferd geeignet. Während Xylazin für den Einsatz bei Pferden zugelassen ist und seit vielen Jahren zur Sedierung verwendet wird, besitzt Dexmedetomidin keine Zulassung für Equiden. Es ist jedoch deutlich potenter als Xylazin und zeichnet sich durch eine hohe Alpha-2-Adrenorezeptor-Selektivität $(\sim 1: 1620)$ aus. Ziel der vorliegenden Studie war die Ermittelung equipotenter Dosierungen von Xylazin und Dexmedetomidin für die Sedierung von Pferden mittels Davertropfsedation (DTI) und für die Eignung als Bestandteil einer Injektionsanästhesie. Hierfür wurden fünf Pferde der Klinik für Pferde der Stiftung Tierärztliche Hochschule Hannover in die Studie einbezogen und drei Mal im Abstand von je 2 Wochen für zwei Stunden sediert. In der Gruppe X erhielten die Tiere einen Bolus von 0,5 mg/kg Körpergewicht Xylazin und die Sedierung wurde mittels $1 \mathrm{mg} / \mathrm{kg} / \mathrm{Std}$ Xylazin aufrecht gehalten. In der Gruppe D1 und D2 wurden die Tiere zunächst mit 3,5 $\mu \mathrm{g} / \mathrm{kg}$ Körpergewicht sediert und erhielten dann eine DTI mit $5 \mu \mathrm{g} / \mathrm{kg} / \mathrm{Std}$. Die Tiere der Gruppe D2 erhielten zudem 0,5 mg Dexmedetomidin-Boli, um einen vergleichbaren Kopf-Boden-Abstand wie die Probanden der Gruppe X zu erreichen. Des Weiteren wurde die thermische Schwelle mittels Thermostimulation ermittelt und zwischen den Gruppen verglichen. Die statistische Auswertung erfolgte mittels 2-faktorieller Varianzanalyse mit wiederholten Messungen und es erfolgte eine Alpha-Adjustierung auf 5\%. Alle Tiere aller Gruppen waren nach dem Bolus Xylazin und auch Dexmedetomidin deutlich sediert und es kann zu einer signifikanten Reduzierung des Kopf-BodenAbstands im Vergleich zur Grundmessung. Weiter kam es zu einem signifikanten Abfall der thermischen Reizschwelle in allen Gruppen. Die Ergebnisse der Studie konnten weiter zeigen, dass in der Gruppe D2 (Bolus 3,5 $\mu \mathrm{g} / \mathrm{kg}$ Dexmedetomidin und DTI mit $5 \mu \mathrm{g} / \mathrm{kg} / \mathrm{Std}$ ) durchschnittlich $2 \mu \mathrm{g} / \mathrm{kg} / \mathrm{Std}$ Dexmedetomidin mehr notwendig notwendig waren, um eine vergleichbare Sedationstiefe zur erreichen wie in der Gruppe X (Bolus 0,5 mg/kg Xylazin und DTI mit $1 \mathrm{mg} / \mathrm{kg} / \mathrm{Std}$ ). Hieraus errechnete sich eine notwendige Infusionsgeschwindigkeit für Dexmedetomidin von $7 \mu \mathrm{g} / \mathrm{kg} / \mathrm{Std}$. Zusammenfassend lässt sich sagen, dass im Rahmen der vorliegenden Studie gezeigt werden konnte, dass ein Bolus mit 3,5 $\mathrm{\mu g} / \mathrm{kg}$ Dexmedetomidin zu einer vergleichbaren Sedierungstiefe wie ein $0,5 \mathrm{mg} / \mathrm{kg}$ Xylazin-Bolus führt. Um eine equisedative Wirkung wie $1 \mathrm{mg} / \mathrm{kg} / \mathrm{Std}$ Xylazin für einen Zeitraum von 2 Stunden zu erreichen, waren $7 \mu \mathrm{g} / \mathrm{kg} / \mathrm{Std}$ Dexmedetomidin notwendig.

Schlüsselwörter: Pferd / Xylazin / Dexmedetomidin / Sedierung / Davertropfinfusion / Anästhesiologie

\section{Introduction}

Xylazine serves as the prototype and was the first $\alpha 2$-adrenoceptor agonist approved for the use in horses (Clarke and Taylor 1986). Intravenous doses of xylazine used for equine chemical restraint range from 0.5-1.1 mg/kg bwt, IV (Muir and Hubbell 2009). Xylazine is less potent and has a lower $\alpha 1$ : $\alpha 2$-selectivity than detomidine, romifidine or medetomidine (Virtanen et al. 1985, Yamashita et al. 2000). Cardiovascular depression is shorter and milder with xylazine than with equipotent doses of medetomidine and detomidine. It causes 
less initial hypertension with a minimal increase in peripheral vascular resistance (Yamashita et al. 2000). The duration of cardiovascular depression seems to parallel the duration of the sedation (Bryant et al. 1991, Wagner et al. 1991). At equisedative doses xylazine produces less ataxia of shorter duration compared to medetomidine (Bryant et al. 1991).

Medetomidine is a highly selective $\alpha 2$-adrenoceptor agonist and is a racemic mixture that contains equal parts of two optical enantiomers, dexmedetomidine and levomedetomidine (Aantaa et al. 1993). Dexmedetomidine is the sedative and analgesic active enantiomer (Aantaa et al. 1993). A dose of $3.5 \mu \mathrm{g} / \mathrm{kg}$ bwt IV of dexmedetomidine was equivalent to 7 $\mu \mathrm{g} / \mathrm{kg}$ bwt IV of medetomidine and was successfully used for sedation in horses (Bettschart-Wolfensberger et al. 2005). In the previously study cardiopulmonary side effects of dexmedetomidine were minimal. With dexmedetomidine, reduction in $\mathrm{HR}$ was not significant, and cardiac index $(\mathrm{Cl})$ was decreased only for the first ten minutes in horses. The initial increase with the following decrease in arterial blood pressure was of shorter duration than with medetomidine or xylazine (Yamashita ef al. 2000, Bettschart-Wolfensberger et al. 2005).

Nociceptive threshold testing can be used as an objective and relatively noninvasive way of assessing responses to analgesic administration and sedative drugs (Love et al. 2011). Thermal threshold testing devices have been developed and validated for use in sheep (Nolan et al. 1987) and cats (Dixon et al. 2002) and a feline thermal threshold testing device has recently been modified and validated for use in horses (Love 2011).

Aim of this study was to elaborate equisedative constant rate infusion regimes of xylazine and dexmedetomidine in awake horses, which would provide a constant level of sedation.

\section{Materials and methods}

Five adult, healthy university-owned horses (three warmbloods, two standardbreds), two geldings and three mares, weighing $540 \pm 52.1 \mathrm{~kg}$ (mean \pm SD) and aged $12 \pm 7.9$ years were used. The experimental protocol was approved by the Ethical Committee of the Lower Saxony State Office for Consumer Protection and Food Safety. The study was carried out as a prospective, randomized experimental cross-over trial. Each horse was tested three times with at least four weeks between trials.

Two hours before sedation, trail the skin over the right and left jugular vein was clipped and surgically prepared. After subcutaneous infiltration with mepivacaine hydrochloride (Scandicain ${ }^{\circledR} 2 \%$, AstraZeneca GmbH, Wedal, Germany), a 13 gauge $(G)$ catheter (Vygonüle S, Vygon $\mathrm{GmbH} \&$ Co. KG, Aachen, Germany) was placed in each jugular vein. One catheter was used for blood sampling, the other for drug administration and was connected to extension tubes (Lectrocath, Laboratoires Pharmaceutiques VYGON, Ecoven, France).

Thermal thresholds (TTs) were measured by a remote controlled TT testing device adapted to the use in horses (Wireless Thermal Threshold Testing System WTT2, Topcat Metrology Ltd, Gravel Head Farm, Little Downham). The probe with a heater element and adjacent temperature sensor was placed above the right nostril and held in place with an elastic strap. Consistent contact between the probe and the skin was ensured by inflating a blood pressure bladder to a constant pressure between 30 and $80 \mathrm{mmHg}$ which was placed between the probe and the elastic strap. The probe was connected to the control unit which was placed over the horse's withers. The rate of heating was $0.8^{\circ} \mathrm{C} / \mathrm{s}$ with a cut-out set at $60^{\circ} \mathrm{C}$ to prevent thermal burns. Before each test, the skin temperature was recorded. The thermal stimulus was applied via a handheld infrared remote control from an operator standing behind the horse. When a positive reaction was observed, heating was terminated and the threshold recorded. A positive reaction was defined as rubbing the nose against the wall or the foreleg, shaking of the head, twitching the nose, turning the head towards the operator or pinning back the ears. Baseline was determined before any treatments were given. The thermal thresholds were determined 15, 30, 60, 90 and 120 min after giving a bolus and starting the infusion of the tested $\alpha 2$-adrenoceptor agonists as well as 30 and $60 \mathrm{~min}$ after stopping the infusion.

After instrumentation horses were placed in stocks with a scale on the wall next to the horses head. Movement of the head was not restricted. For baseline determination the animals were observed for one hour. The mean of these measurements were defined as baseline. In five minutes intervals heart rate $(H R)$ (via ECG, Televet ${ }^{\circledR}$ Engel Engineering Services $\mathrm{GmbH}$, Offenbach, Germany), respiratory rate (RR) and the distance between ground and the rostral part of the nostrils (NGD) were recorded. The baseline NGD was set as $100 \%$. For group X, horses received xylazine (Xylazin ${ }^{\circledR} 2 \%$, CP-pharma GmbH, Burgdorf, Germany). A bolus of $0.5 \mathrm{mg} / \mathrm{kg}$ bwt IV was administered over a period of two minutes followed by a CRI of $1 \mathrm{mg} / \mathrm{kg}$ bwt/h xylazine IV over $120 \mathrm{~min}$.

For group D1, horses were treated with an initial bolus of 3.5 $\mu \mathrm{g} / \mathrm{kg}$ but dexmedetomidine IV (Dexdomitor ${ }^{\circledR} 0.5 \mathrm{mg} / \mathrm{ml}$, Orion-Farmos, Turku, Finland) followed by a CRI of $5 \mu \mathrm{g} / \mathrm{kg}$ bwt/h.

The NGD was recorded in both groups and the reduction of NGD in percent was calculated. Since the tested dexmedetomidine dose did not achieve the same NGD as the xylazine protocol, a third trial was added (group D2). The percentage of NGD reduction in each horse after xylazine was transferred to the current baseline NGD and defined as threshold. Horses were treated with a bolus of $3.5 \mu \mathrm{g} / \mathrm{kg}$ bwt IV dexmedetomidine followed by a CRI of $5 \mu \mathrm{g} / \mathrm{kg} \mathrm{bwt} / \mathrm{h}$ IV. If the nostril position was higher than the previously defined threshold with a range of five per cent, a $0.5 \mathrm{mg}$ bolus of dexmedetomidine was injected. The number of required injections and the total dexmedetomidine dose over the infusion period were calculated.

After the two hours of CRI the time to regain normal head position was noted and the percentage of reduction of the NGD compared to baseline was calculated.

Goodness of fit for normal distribution of model residuals of data was performed by visual assessment of normal probability plots and the Shapiro-Wilk test. Data are presented as mean $\pm S D$. A two-way analysis of variance with repeated 
measurements with post hoc Dunnett's t-test was used to analyse changes in heart rate, respiratory rate, NGD and thermal thresholds. Analyses was carried out with the statistical software SAS, version 9.2 (SAS Institute, Cary, NC). Values of $p<0.05$ were considered significant.

\section{Results}

All horses developed signs of moderate to deep sedation including moderate ataxia. After bolus administration no $(X)$, two (D1) and one (D2) horse developed first-degree atrioventricular blocks (AV-blocks), and five (X), three (D1) and three (D2) horses developed second-degree AV-blocks. During infusion two $(X)$, one (D1) and three (D2) horses showed firstdegree AV-blocks and one (X), two (D1) and three (D2) horses had second degree AV-blocks. Heart rate was significantly decreased from baseline values over the majority of the 120 min infusion period with no significant differences between groups. Respiratory rate decreased significantly from baseline over the whole 120 min treatment period in group D2.

The NGD was significantly reduced from time 0 until 135 min, from time 5 until 120 min and from time 5 until 135 min in group $X$, group D1 and group D2, respectively (Figure 1). There was no statistically significant difference between groups.

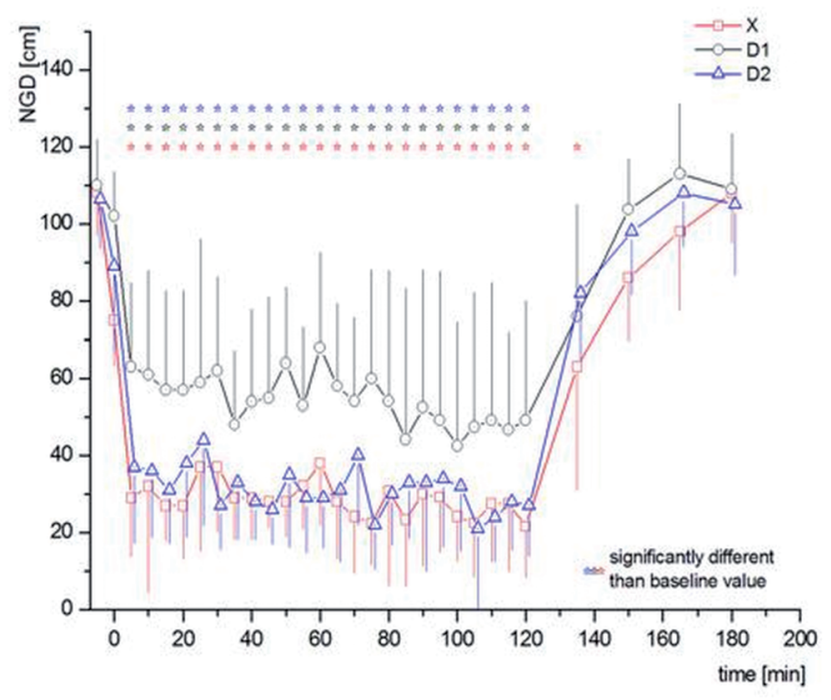

Fig. 1 Mean \pm SD nose-to-ground-distance (NGD) in 5 horses after xylazine $(0.5 \mathrm{mg} / \mathrm{kg}$ bwt and $1 \mathrm{mg} / \mathrm{kg} / \mathrm{h})[\mathrm{X}]$, dexmedetomidine $(3.5 \mu \mathrm{g} / \mathrm{kg}$ bwt and $5 \mu \mathrm{g} / \mathrm{kg} / \mathrm{h})$ [D1] or dexmedetomidine $(3.5 \mu \mathrm{g} / \mathrm{kg}$ bwt and $7 \mu \mathrm{g} / \mathrm{kg} / \mathrm{h}$ ) [D2] from 0 to $120 \mathrm{~min}$.

Thermal thresholds increased significantly above baseline from time 15 and remained significant higher until $120 \mathrm{~min}$ in group $X$ and D1 and until 150 min in group D2 (Figure 2). There was no significant difference between groups. The $95 \%$ confidence interval $(\mathrm{Cln})$ of TTs increased above the upper $95 \% \mathrm{Cln}$ of baseline measurements after $15 \mathrm{~min}$ in group $X$ and D2.

In group D2 a calculated CRI of $7 \mu \mathrm{g} / \mathrm{kg}$ bwt $/ \mathrm{h}$ dexmedetomidine (after initial bolus of $3.5 \mu \mathrm{g} / \mathrm{kg} \mathrm{bwt)} \mathrm{was} \mathrm{necessary} \mathrm{to}$ reach the same reduction of NGD than a CRI of $1 \mathrm{mg} / \mathrm{kg}$ bwt/h of xylazine (after bolus of $0.5 \mathrm{mg} / \mathrm{kg} \mathrm{bwt).}$

\section{Discussion}

The study was designed to determine an equipotent dose of dexmedetomidine and xylazine suitable for sedation and constant rate infusion to be used as part of TIVA in horses.

The extent and duration of head drop was the main criterion to evaluate sedation in our horses, which is an accepted method to assess $\alpha 2$-adrenoceptor agonist induced sedation (Kamerling et al. 1988, Bryant et al. 1991, Bettschart-Wolfensberger et al. 1999). The bolus of $0.5 \mathrm{mg} / \mathrm{kg}$ bwt followed by a CRI of $1 \mathrm{mg} / \mathrm{kg}$ bwt/h xylazine IV was set as the reference for depth of sedation. A common sedative dose of xylazine before induction of anaesthesia with ketamine is 1.0 or $1.1 \mathrm{mg} / \mathrm{kg}$ bwt IV (Greene et al. 1986, Young et al. 1993, Bettschart-Wolfensberger et al. 1996, Muir et al. 2000, Oku et al. 2005, Rezende et al. 2010). Clinical experience with our population of horses showed, that horses became very atactic and one horse collapsed after a bolus of $1 \mathrm{mg} / \mathrm{kg}$ bwt IV. This was comparable to results of a dose-finding trail sedating horses with $1 \mathrm{mg} / \mathrm{kg}$ btw IV before starting CRI (Ringer et al. 2012). Therefore we decided to reduce the bolus of xylazine used for sedation to $0.5 \mathrm{mg} / \mathrm{kg}$ bwt IV. The xylazine bolus reduced NGD by $73 \%$ five minutes after the end of the injection. The bolus of $3.5 \mu \mathrm{g} / \mathrm{kg}$ bwt of dexmedetomidine resulted in a reduction of $43 \%$ and $64 \%$ in group D1 and D2, respectively. The difference between NGD after the

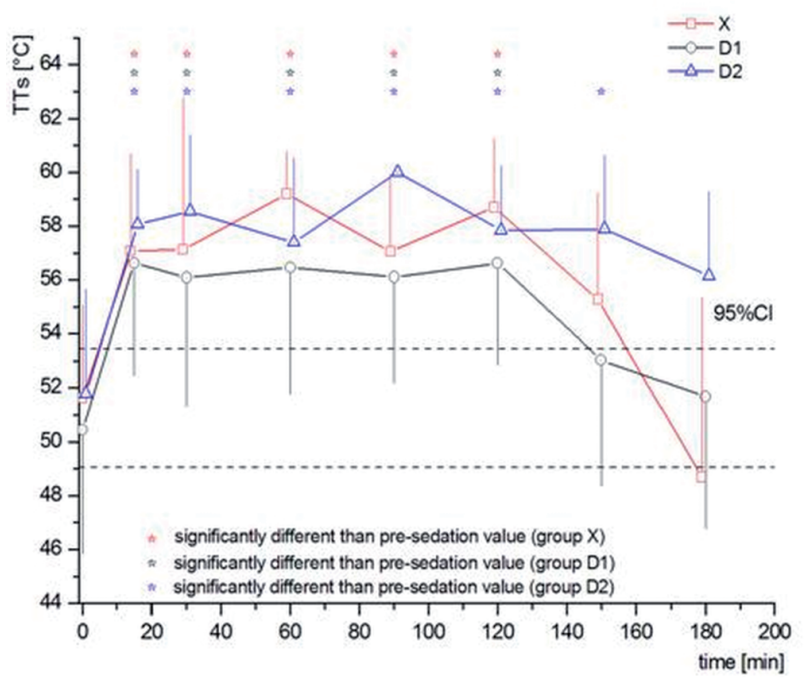

Fig.2 Thermal threshold temperature (mean, $\mathrm{Cln}$ ) in 5 horses after xylazine $(0.5 \mathrm{mg} / \mathrm{kg}$ bwt and $1 \mathrm{mg} / \mathrm{kg} / \mathrm{h})[\mathrm{X}]$, dexmedetomidine $(3.5 \mu \mathrm{g} / \mathrm{kg}$ bwt and $5 \mu \mathrm{g} / \mathrm{kg} / \mathrm{h})$ [D1] or dexmedetomidine $(3.5 \mu \mathrm{g} / \mathrm{kg}$ bwt and $7 \mu \mathrm{g} / \mathrm{kg} / \mathrm{h}$ ) [D2] from 0 to 120 . Reading at time $0=$ mean of four pre-treatment measurements. $95 \% \mathrm{Cln}$ of pre treatment thresholds.

same dexmedetomidine bolus in group D1 and D2 is hard to explain and might be related to differences in initial sympathetic tone of the horses. Because of the study design the group D2 (additional boli of dexmedetomidine) was always the last trial and therefore horses might have been familiarized with the study set up resulting in less excitement allowing better sedation.

In a previous study performed in ponies a dose of $3.5 \mu \mathrm{g} / \mathrm{kg}$ bwt dexmedetomidine was considered to be equisedative to 7 
$\mu \mathrm{g} / \mathrm{kg}$ bwt medetomidine (Bettschart-Wolfensberger et al. 2005). A further trail on warmblood horses considered 7.7 $\mu \mathrm{g} / \mathrm{kg}$ bwt medetomidine and $1 \mathrm{mg} / \mathrm{kg}$ bwt xylazine being equisedative (Yamashita et al. 2000). In present study a xylazine bolus of $0.5 \mathrm{mg} / \mathrm{kg}$ bwt resulted in a greater NGD reduction than a dexmedetomidine bolus of $3.5 \mu \mathrm{g} / \mathrm{kg}$ bwt. If our horse population in the current study was overly sensitive to xylazine effects remains unknown.

To obtain the level of sedation in group D2 comparable to group $X$ a mean of six further boli of $0.5 \mathrm{mg}$ dexmedetomidine boli were necessary. Then the individual infusion rate was calculated, which resulted in a dexmedetomidine CRI of 7 $\mu \mathrm{g} / \mathrm{kg} \mathrm{bwt} / \mathrm{h}$. This dose resulted in reduction of NGD by $70 \%$ which was greater compared to a study of Bettschart-Wolfensberger et al. (1999) in which ponies had a constant head drop of $50 \%$ for two hours after a medetomidine bolus of 5 $\mu \mathrm{g} / \mathrm{kg}$ followed by a CRI of $3.5 \mu \mathrm{g} / \mathrm{kg} / \mathrm{h}$. Considering a potency ratio of 1:2 between medetomidine and dexmedetomidine on receptor binding studies (Virtanen 1989), the high dose of dexmedetomidine for CRI used in the current study was four times higher than the dose used in the ponies.

The 2-adrenoceptor agonist drugs produce excellent analgesia in horses (Kamerling et al. 1988, England and Clarke 1996). Noxious thermal stimulation is considered to be an objective and repeatable method for assessing cutaneous analgesia in horses (Kamerling et al. 1985, Kamerling et al. 1988, Robertson et al. 2005). While noxious electrical stimulation of the skin preferentially activates small myelinated A' fibers which are responsible for the initiation of pain ("first pain"), noxious thermal stimuli activate additionally slowly conducting C-fibers, which have been associated with persistent clinical or chronic pain (Gaynor and Muir 2009). Results from the present study demonstrated an increase in thermal threshold following xylazine and dexmedetomidine administration which may be related to analgesic action of these drugs. This effect was dose depending in the dexmedetomidine groups. Although there was no significant difference between groups, mean values for thermal threshold after low dose dexmedetomidine were consistently lower. A high density of $\alpha 2$ adrenoceptor agonists have been demonstrated in lamina II of the dorsal horn of the spinal cord (Bouchenafa and Livingston 1987), which is an area widely implicated in the transmission of painful stimuli. Noxious stimulation at the area over the right nostril is transmitted via the sensory infraorbital nerve as part of the trigeminal nerve and does not involve the dorsal horn of the spinal cord. Thus, produced analgesia must basically result from activation of $\alpha 2$-adrenoceptors located in the locus coeruleus and the periaqueductal gray mater (Guo et al. 1996, Peng et al. 1996, Budai et al. 1998).

Cardiopulmonary changes produced by different $\alpha 2$-adrenoceptor agonists in horses are similar (England and Clarke 1996). The haemodynamic effects include the typical biphasic blood pressure response with decreased heart rate and cardiac index as well as an increase in systemic vascular resistance (England and Clarke 1996). In the current trial, the heart rate decreased significantly after bolus injection and remained low with CRI of xylazine as well as both dexmedetomidine doses. In contrast, (Bettschart-Wolfensberger et al. 2005) reported no significant reduction in heart rate after a bolus of $3.5 \mu \mathrm{g} / \mathrm{kg}$ bwt dexmedetomidine IV in ponies. In the current study there was no significant difference in reduction of heart rate between groups D1 and D2. Studies in humans suggest that increasing concentrations of dexmedetomidine during $C R I$ resulted in a decrease in $H R$, a progressive decrease in $\mathrm{CO}$, and a biphasic (low, then high) dose-response relation for arterial blood pressure and vascular resistance because of peripheral vaso- and venoconstriction, so that cardiovascular effects might limit the usefulness of high concentrations of dexmedetomidine (Ebert et al. 2000).

In conclusion, a dose regime with a bolus of $0.5 \mathrm{mg} / \mathrm{kg}$ bwt xylazine followed by a CRI with $1 \mathrm{mg} / \mathrm{kg}$ bwt/h of was equisedative to a bolus of $3.5 \mu \mathrm{g} / \mathrm{kg}$ bwt dexmedetomidine followed by $7 \mu \mathrm{g} / \mathrm{kg}$ bwt $/ \mathrm{h}$ of and produced a constant level of sedation. A dose of $3.5 \mu \mathrm{g} / \mathrm{kg}$ bwt and following $5 \mu \mathrm{g} / \mathrm{kg}$ $\mathrm{bwt} / \mathrm{h}$ of dexmedetomidine produced less sedation, but a comparable decrease of heart rate. However, further investigations are required to assess the suitability of these dose regimes as part of TIVA, its cardiopulmonary and analgesic effects as well as its combination with other anaesthetic drugs.

\section{Conflict of interest statement}

None of the authors of this paper has a financial or personal relationship with other people or organisations that could inappropriately influence or bias the content of this paper.

\section{References}

Aantaa R., Kallio A. and Virtanen R. (1993) Dexmedetomidine, a novel alpha2-adrenergiv agonist. A review of its pharmacodynamic characteristics. Drugs of the Future 18, 49-56

Bettschart-Wolfensberger R., Clarke K. W., Vainio O., Aliabadi F. and Demuth D. (1999) Pharmacokinetics of medetomidine in ponies and elaboration of a medetomidine infusion regime which provides a constant level of sedation. Res. Vet. Sci. 67, 41-46

Bettschart-Wolfensberger R., Freeman S. L., Bowen I. M., Aliabadi F. S., Weller R., Huhtinen M. and Clarke K. W. (2005) Cardiopulmonary effects and pharmacokinetics of i.v. dexmedetomidine in ponies. Equine Vet. J. 37, 60-64

Bettschart-Wolfensberger R., Taylor P. M., Sear J. W., Bloomfield M. R., Rentsch K. and Dawling S. (1996) Physiologic effects of anesthesia induced and maintained by intravenous administration of a climazolam-ketamine combination in ponies premedicated with acepromazine and xylazine. Am. J. Vet. Res. 57, 1472-1477

Bouchenafa $O$. and Livingston A. (1987) Autoradiographic localisation of alpha 2 adrenoceptor binding sites in the spinal cord of the sheep. Res. Vet. Sci. 42, 382-386

Bryant C. E., England G. C. and Clarke K. W. (1991) Comparison of the sedative effects of medetomidine and xylazine in horses. Vet. Rec. 129, $421-423$

Budai D., Harasawa l. and Fields H. L. (1998) Midbrain periaqueductal gray (PAG) inhibits nociceptive inputs to sacral dorsal horn nociceptive neurons through alpha2-adrenergic receptors. J. Neurophysiol. 80, 2244-2254

Clarke K. W. and Taylor P. M. (1986) Detomidine: a new sedative for horses. Equine Vet. J. 18, 366-370

Dixon M. J., Robertson S. A. and Taylor P. M. (2002) A thermal threshold testing device for evaluation of analgesics in cats. Res. Vet. Sci. 72, 205-210

Ebert T. J., Hall J. E., Barney J. A., Uhrich T. D. and Colinco M. D. (2000) The effects of increasing plasma concentrations of dexmedetomidine in humans. Anesthesiology 93, 382-394

England G. C. and Clarke K. W. (1996) Alpha 2 adrenoceptor agonists in the horse-a review. Br. Vet. J. 152, 641-657

Gaynor J. S. and Muir W. W. (2009) Veterinary Pain Managment. $\alpha 2$ Agonists Mosby Elsevier 
Greene S. A., Thurmon J. C., Tranquilli W. J. and Benson G. J. (1986) Cardiopulmonary effects of continuous intravenous infusion of guaifenesin, ketamine, and xylazine in ponies. Am. J. Vet. Res. 47, 2364-2367

Guo T. Z., Jiang J. Y., Buttermann A. E. and Maze M. (1996) Dexmedetomidine injection into the locus ceruleus produces antinociception. Anesthesiology 84, 873-881

Kamerling S. G., Cravens W. M. and Bagwell C. A. (1988) Objective assessment of detomidine-induced analgesia and sedation in the horse. Eur. J. Pharmacol. 151, 1-8

Kamerling S. G., Weckman T. J., DeQuick D. J. and Tobin T. (1985) A method for studying cutaneous pain perception and analgesia in horses. J. Pharmacol. Methods 13, 267-274

Love E. J., Murrell J. and Whay H. R. (2011) Thermal and mechanical nociceptive threshold testing in horses: a review. Vet. Anaesth. Analg. 38, 3-14

Muir W. W. and Hubbell J. A. (2009) Equine Anesthesia: Monitoring and Emergency Therapy. Vol. Second Edition. Anxiolytics, Nonopioid Sedative-Analgesics, and Opioid Analgesics. Saunders Elsevier, St. Louis, Missouri 63146

Muir W. W., Lerche P., Robertson J. T., Hubbell J. A., Beard W., Miller T., Badgley B. and Bothwell V. (2000) Comparison of four drug combinations for total intravenous anesthesia of horses undergoing surgical removal of an abdominal testis. J. Am. Vet. Med. Assoc. 217, 869-873

Nolan A. M. and Hall L. W. (1984) Combined use of sedatives and opiates in horses. Vet. Rec. 114, 63-67

Oku K., Ohta M., Yamanaka T., Mizuno Y. and Fujinaga T. (2005) The minimum infusion rate (MIR) of propofol for total intravenous anesthesia after premedication with xylazine in horses. J. Vet. Med. Sci. 67, 569-575

Peng Y. B., Lin Q. and Willis W. D. (1996) Involvement of alpha-2 adrenoceptors in the periaqueductal gray-induced inhibition of dorsal horn cell activity in rats. J. Pharmacol. Exp. Ther. 278, 125-135

Rezende M. L., Boscan P., Stanley S. D., Mama K. R. and Steffey E. $P$. (2010) Evaluation of cardiovascular, respiratory and biochemical effects, and anesthetic induction and recovery behavior in horses anesthetized with a $5 \%$ micellar microemulsion propofol formulation. Vet. Anaesth. Analg. 37, 440-450

Ringer S. K., Portier K. G., Fourel I. and Bettschart-Wolfensberger R. (2012) Development of a romifidine constant rate infusion with or without butorphanol for standing sedation of horses. Vet. Anaesth. Analg. 39, 12-20

Robertson S. A., Sanchez L. C., Merritt A. M. and Doherty T. J. (2005) Effect of systemic lidocaine on visceral and somatic nociception in conscious horses. Equine Vet. J. 37, 122-127

Virtanen $R$ (1989) Pharmacological profiles of medetomidine and its antagonist, atipamezole. Acta Vet. Scand. Suppl. 85, 29-37

Virtanen R., Ruskoaho H. and Nyman L. (1985) Pharmacological evidence for the involvement of alpha-2 adrenoceptors in the sedative effect of detomidine, a novel sedative-analgesic. J. Vet. Pharmacol. Ther. 8, 30-37

Wagner A. E., Muir W. W. and Hinchcliff K. W. (1991) Cardiovascular Effects of Xylazine and Detomidine in Horses. Am. J. Vet. Res. $52,651-657$

Yamashita K., Tsubakishita S., Futaoka S., Ueda I., Hamaguchi H., Seno T., Katoh S., Izumisawa Y., Kotani T. and Muir W. W. (2000) Cardiovascular effects of medetomidine, detomidine and xylazine in horses. J. Vet. Med. Sci. 62, 1025-1032

Young L. E., Bartram D. H., Diamond M. J., Gregg A. S. and Jones R. S. (1993) Clinical evaluation of an infusion of xylazine, guaifenesin and ketamine for maintenance of anaesthesia in horses. Equine Vet. J. 25, 115-119

Dr. Klaus Hopster, DipECVAA

Klinik für Pferde

Stiffung Tierärztliche Hochschule Hannover

Bünteweg 17

30559 Hannover

Germany

klaus.hopster@tiho-hannover.de 